Proc. Estonian Acad. Sci. Biol. Ecol., 2006, 55, 4, 280-307

\title{
Ecological processes in macrophyte- and phytoplankton-dominated shallow lakes
}

\author{
Priit Zingel $^{\mathrm{a}, \mathrm{b} *}$, Peeter Nõges ${ }^{\mathrm{a}}$, Lea Tuvikene ${ }^{\mathrm{a}}$, Tõnu Feldmann ${ }^{\mathrm{a}, \mathrm{c}}$, \\ Ain Järvalt ${ }^{\mathrm{a}}$, Ilmar Tõnno ${ }^{\mathrm{a}}$, Helen Agasild ${ }^{\mathrm{a}, \mathrm{c}}$, Helen Tammert ${ }^{\mathrm{a}, \mathrm{d}}$, \\ Helen Luup ${ }^{\mathrm{a}}$, Jaana Salujõ $e^{\mathrm{a}, \mathrm{c}}$, and Tiina Nõges ${ }^{\mathrm{a}}$ \\ ${ }^{\text {a }}$ Centre for Limnology, Institute of Agriculture and Environmental Research, Estonian University \\ of Life Sciences, 61101 Rannu, Tartumaa, Estonia \\ b Institute of Veterinary Medicine and Animal Sciences, Estonian University of Life Sciences, \\ Kreutzwaldi 1, 51015 Tartu, Estonia \\ ${ }^{c}$ Institute of Zoology and Hydrobiology, University of Tartu, Vanemuise 46, 51014 Tartu, Estonia \\ ${ }^{d}$ Institute of Botany and Ecology, University of Tartu, Lai 40, 51005 Tartu, Estonia \\ Received 11 April 2005, in revised form 11 November 2005

\begin{abstract}
Stratified lakes often receive more attention from limnologists although most of the world's lakes are indeed shallow. This study describes ecological processes in three shallow lakes, one dominated by macrophytes, one by phytoplankton, and one with both of them. Investigations focused on abiotic (water chemistry) as well as biotic factors such as phytoplankton, bacteria, zooplankton, and macrophytes. The macrophyte- and plankton-dominated lakes differed clearly in water transparency, which was far greater in macrophyte-dominated lakes due to phytoplankton setback in summer. Similar nutrient and zooplankton dynamics occurred in both types of lakes, suggesting that an alternative mechanism may account for the observed phytoplankton decline in macrophyte lakes. In contrast, herbivorous ciliates dominated only in the macrophyte lake. More intensive ciliate grazing could be one factor causing a decrease in phytoplankton numbers. In the plankton-dominated lake bacteria were mostly related to phytoplankton production but that was not the case in the macrophytedominated lake. In the plankton-dominated lake the grazing rate of ciliates on bacteria was higher than in the macrophyte-dominated one. However, when grazing on small algae was considered, the highest grazing rates were found in the macrophyte-dominated lake. This suggests that the microbial loop was weaker in the macrophyte-dominated lake than in the plankton-dominated lake.
\end{abstract}

Key words: shallow lakes, aquatic food webs, macrophyte-dominated lake, phytoplankton-dominated lake.

\footnotetext{
* Corresponding author, pzingel@zbi.ee
} 


\section{INTRODUCTION}

The most classical fundamental studies on lake ecology have been done in relatively deep lakes, which are in summer subject to thermal and chemical stratification (e.g. Hutchinson, 1957, 1967). Thermal stratification largely isolates the upper water layer (epilimnion) from the colder deep water (hypolimnion) and from interaction with the accumulation sediment during summer. So the hypolimnion is usually cold, dark, and rich in nutrients (nitrogen and phosphorus) but unproductive. In such lakes the impact of macrophytes on the community is relatively small, as plant growth is restricted to a narrow marginal zone. A large number of lakes that do not undergo stratification also exist. In these lakes, the entire water column is frequently mixed (polymictic) and kept in contact with sediments. The functioning of that kind of ecosystem differs completely from the "classical" lake type and deserves also a completely different theoretical approach (Scheffer, 1998). Comprehensive theoretical studies about shallow lake ecosystems started to emerge only in the last decade (Kufel et al., 1997; Moss et al., 1997; Scheffer, 1998; Jeppesen et al., 1998) and their authors agree that there is still much unknown.

The clear-water, macrophyte-dominated state is considered the pristine condition in shallow lakes (Scheffer, 1998). Nutrient loading has caused the water to turn turbid and with the increase in turbidity, submerged plants have largely disappeared. The macrophytes seem to have the key position in the development of the ecological state in shallow lakes (Jeppesen et al., 1998). Lakes with a low nutrient content have usually a vegetation dominated by relatively small plants. With moderate nutrient loading, the biomass and proportion of aquatic macrophytes increase and plants can fill the entire water column. However, with further eutrophication phytoplankton can gain the upper hand. Disappearance of macrophytes changes the lake ecosystem so drastically that the new phytoplankton-dominated system can be regarded as a new stable state. By the state-of-art theory, two alternative stable states exist for shallow lakes (Scheffer, 1998) - the vegetationdominated clear state and the turbid phytoplankton-dominated state. Switches between the two stable states can be abrupt; the ecosystem's response to increasing eutrophication is not linear but follows the sigmoidal hysteresis curve (Scheffer, 1998). When the nutrient loading to a macrophyte-dominated lake first increases, the low phytoplankton biomass and low turbidity can still prevail for quite a long time. Macrophytes can prevent wave resuspension, affect nutrient availability in the water column, influence algal growth through allelopathic exudates, and harbour high densities of phytoplankton eating cladocerans. When these stabilizing mechanisms are suddenly somehow eliminated (e.g destruction of vegetation by human or introduced bird or fish species, water-level changes, changes in salinity, destruction by predatory fish, etc.) the ecosystem will switch to a new stable state with turbid water and phytoplankton dominance. It can happen also when nutrient loading increases to such a level that phytoplankton grows so fast in spring that 
they inhibit macrophyte growth by shading and light limitation. When macrophytes are gone, increased wave resuspension will act as a positive feedback from the increased turbidity and sediment nutrient release. The macrophytes cannot return now even when the amount of nutrients decreases. So, a switch back to the clear water state can only occur in circumstances when the nutrient concentrations are significantly lower than those when switching to the turbid state occurred.

Still we are a long way from a full comprehension of the shallow lakes ecosystem, which includes a full set of physical-chemical (bottom-up) and biological (top-down) interactions (Jensen et al., 1994; Jeppesen et al., 1998). When a lake has a low nutrient content, phytoplankon cannot achieve enough biomass to hinder macrophyte growth. However, with increased nutrient loading, these responses are less predictable. We may get an algae-dominated lake where the only limiting factor for phytoplankton growth is their own density. On the other hand, we have evidence from lakes where nutrient concentrations are very high but zooplankton suppress algal biomass, water is clear, and macrophytes are strongly present.

Because of insufficient knowledge about the shallow lake ecosystems we cannot adequately predict their future in the rapidly changing global environment. Also the results of different restoration methods remain incalculable. The aim of this study was to describe some key ecological processes and communities in three macrophyte- and/or phytoplankton-dominated shallow lakes focusing on phytoplankton, bacteria, and meta- and protozooplankton.

\section{MATERIAL AND METHODS}

In 2000 we sampled seasonally three shallow lakes of varying ecological status: L. Kaiavere - a eutrophic plankton-dominated lake, L. Prossa - a eutrophic macrophyte-dominated lake, L. Võrtsjärv - a eutrophic lake, the central part of which was studied separately as a plankton-dominated lake and the southern part as a macrophyte-dominated one. To obtain a wide range of background data, in July and August we sampled three additional shallow lakes: dyseutrophic L. Valguta Mustjärv (henceforth L. Mustjärv) semidystrophic L. Uljaste, and halotrophic L. Mullutu Suurlaht (L. Suurlaht) (Tables 1 and 2).

The studied lakes Prossa and Kaiavere are calcareous eutrophic shallow lakes. The bottom of L. Prossa is carpeted with a dense macrophyte cover dominated by Chara spp. Lake Kaiavere has a comparable depth but is larger and the coverage by submerged plants was much smaller and consisted mainly of Potamogeton spp. Võrtsjärv is a large and shallow eutrophic lake. During the vegetation period, Secchi depth usually does not exceed $1 \mathrm{~m}$ in the central parts of the lake and water blooms are a common phenomenon. Besides this, the shallowness of the lake and the waveinduced resuspension of bottom sediments contribute to the formation of a high seston concentration and high turbidity during summer. The southern part is more 
Table 1. Some background information on the studied shallow lakes

\begin{tabular}{l|c|c|r|l|l}
\hline \multicolumn{1}{c|}{ Lake } & $\begin{array}{c}\text { Average } \\
\text { depth, } \mathrm{m}\end{array}$ & $\begin{array}{c}\text { Max } \\
\text { depth, } \mathrm{m}\end{array}$ & $\begin{array}{c}\text { Area, } \\
\text { ha }\end{array}$ & Geology & \multicolumn{1}{c}{ Type } \\
\hline Prossa & 2.2 & 4.2 & 33 & Calc/rock & Eutrophic-macrophyte \\
Kaiavere & 2.8 & 5 & 251 & Calc/rock & Eutrophic-plankton \\
Võrtsjärv & 2.8 & 6 & 27000 & Calc/rock & Eutrophic-plankton \\
Harku & 1.6 & 2.5 & 164 & Calc/rock & Eutrophic-plankton \\
Maardu & 1.6 & 3.2 & 170 & Calc/rock & Dyseutrophic-macrophyte \\
Kirikumäe & 2.8 & 3.5 & 64 & Org/peat & Semidystrophic \\
Suurlaht & 1.2 & 2.1 & 5900 & Calc/rock & Halotrophic \\
Uljaste & 2 & 5.6 & 60 & Org/peat & Semidystrophic \\
Mustjärv & 0.8 & 1 & 23 & Org/peat & Dyseutrophic
\end{tabular}

Table 2. Average annual values for some physico-chemical and biological parameters of the studied shallow lakes $(\mathrm{Sec}=\mathrm{Secchi}$ depth, $\mathrm{Chl} \mathrm{a}=$ chlorophyll $a, \mathrm{TP}=$ total phosphorous, $\mathrm{TN}=$ total nitrogen, $\mathrm{PP}=$ primary production, $\mathrm{BA}=$ bacterial abundance, $\mathrm{PA}=$ autotrophic picoplankton abundance, $\mathrm{Phy} \mathrm{B}=$ phytoplankton biomass, $\mathrm{CA}=$ abundance of ciliates, $\mathrm{CB}=$ biomass of ciliates, MZP A = metazooplankton abundance, MZP B = metazooplankton biomass)

\begin{tabular}{|c|c|c|c|c|c|c|c|c|c|c|c|c|}
\hline 恙 & $\stackrel{\tilde{D}}{n} \Xi$ & 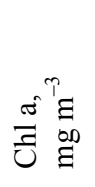 & 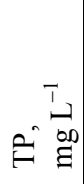 & 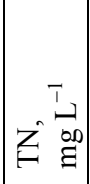 & 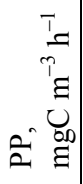 & 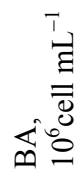 & 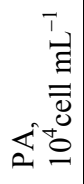 & 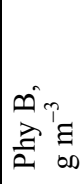 & 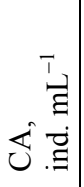 & ص & 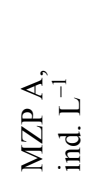 & 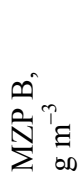 \\
\hline Harku & 0.3 & 230.4 & 0.2 & 2.8 & & & & 34.8 & & & 3064.9 & 1.5 \\
\hline Maardu & 2.5 & 9.6 & 0.0 & 0.8 & & & & 1.0 & & & 1000.2 & 1.1 \\
\hline Kirikumäe & 1.2 & 9.0 & 0.0 & 0.7 & & & & 3.2 & & & 390.3 & 1.0 \\
\hline Suurlaht & 1.5 & 11.3 & 0.0 & 1.4 & 27.7 & 1.9 & 22.7 & 2.1 & 10.9 & 24.5 & 519.7 & 0.3 \\
\hline Uljaste & 1.8 & 54.8 & 0.0 & 0.7 & 17.6 & 0.9 & 3.8 & 7.5 & 14.4 & 60.9 & 357.4 & 3.8 \\
\hline Mustjärv & 0.6 & 17.0 & 0.0 & 1.1 & 32.0 & 1.8 & 1.5 & 1.5 & 19.1 & 122.6 & 2048.3 & 0.2 \\
\hline
\end{tabular}

sheltered from the wave-induced disturbance than the northern part and is largely covered with submerged plants. During seasonal studies we gathered samples for water chemistry, phyto-, zoo-, and bacterioplankton, and measured primary and bacterial production, zooplankton filtering rate, and molecular nitrogen fixation. In July and August we measured in addition the number and species composition of macrophytes and the amount of periphyton on them and the quantity and species composition of chydorids and fishes.

In 2001 we sampled seasonally two shallow lakes: L. Kaiavere and L. Prossa. Starting from the end of April to the middle of June we sampled L. Prossa weekly to examine the development of macrophytes and the shift to a clear-water state. To widen the range of the study, we sampled in August three additional shallow 
lakes: L. Kirikumäe, L. Harku, and L. Maardu (Tables 1 and 2). During seasonal studies we gathered samples for water chemistry, phyto-, zoo-, and bacterioplankton, chydorids, and measured primary and bacterial production, zooplankton filtering rate, number and species composition of macrophytes, and the amount of epiphyton on them.

\section{Water chemistry}

Water temperature and the concentration of dissolved oxygen were monitored in the surface layer, at depths of $0.5 \mathrm{~m}$ and $1 \mathrm{~m}$, and every metre down to the bottom using a Marvet Junior dissolved oxygen meter (Estonia, Tallinn). For other measurements, 2-litre water samples were taken from the above-mentioned depths with a Ruttner bathometer. These samples were mixed in a 30-litre container to get an average sample. Conductivity was measured with HACH conductivity/ TDS meter (model 44600; USA), and pH was estimated using WTW Universal Pocket Meter Multiline P4 (Wissenschaftlich-Technische Werkstätten GMBH, Weilhein, Germany). The concentrations of total phosphorus (TP), inorganic phosphate $\left(\mathrm{PO}_{4}-\mathrm{P}\right)$, nitrates $\left(\mathrm{NO}_{3}-\mathrm{N}\right)$, nitrites $\left(\mathrm{NO}_{2}-\mathrm{N}\right)$, and ammonium nitrogen $\left(\mathrm{NH}_{4}-\mathrm{N}\right)$ were estimated from unfiltered subsamples using standard methods described in (Grasshoff et al., 1999). The concentration of inorganic nitrogen forms (Nmin) was calculated as the sum of $\mathrm{NO}_{3}-\mathrm{N}, \mathrm{NO}_{2}-\mathrm{N}$, and $\mathrm{NH}_{4}-\mathrm{N}$. A spectrophotometer Spekol 11 (Carl Zeiss, Jena) was used for extinction measurements. Total nitrogen (TN) was determined by second-derivative UV spectroscopy (Crumpton et al., 1992), using an UV-visible scanning spectrophotometer Cecil 3000 (Cecil Instruments Ltd, Milton Technical Centre).

\section{Phytoplankton, primary production, and molecular nitrogen fixation}

Integral lake water $(250 \mathrm{~mL})$ was collected for phytoplankton (Phy) analyses and fixed with Lugol's solution ( $0.5 \%$ of final concentration). The samples were counted with an inverted microscope at $\times 400$ magnification using the standard Utermöhl (1958) technique. The mean volume of each species was estimated in all samples by approximating the shape of species to the nearest simple geometric solid.

Chlorophyll $a$ was extracted in $96 \%$ ethanol and analysed spectrophotometrically (Edler, 1979; Arvola, 1981). Primary production (PP) of Phy was estimated in situ using the ${ }^{14} \mathrm{CO}_{2}$ assimilation technique introduced first by Steeman-Nielsen (1952). Depth integrated water was poured to $24 \mathrm{~mL}$ glass scintillation vials, $50 \mu \mathrm{L}$ of sterile $\mathrm{NaH}^{14} \mathrm{CO}_{3}$ (VKI, Denmark) solution $(1.7 \mu \mathrm{Ci}$ per vial) was added to achieve final activity of $0.07 \mu \mathrm{Ci} \mathrm{mL}^{-1}$. Vials were incubated for $2 \mathrm{~h}$ at six depths in the lake. Then $6 \mathrm{~mL}$ of water from each sample was poured into a clean glass scintillation vial and acidified $(\mathrm{pH}<2)$ by adding $150 \mu \mathrm{L}$ of 
$0.5 \mathrm{~N} \mathrm{HCl}$. Inorganic ${ }^{14} \mathrm{C}$ was assumed to be removed during $24 \mathrm{~h}$ (Niemi et al., 1983; Hilmer \& Bate, 1989; Lignell, 1992). Next, $5 \mathrm{~mL}$ subsamples were poured into new plastic vials. The radioactivity of water, filtrate, and filters was assessed by LSC RackBeta 1211 (Wallac, Finland) using external standardization for DPM calculations. Scintillation cocktail Ecoscint A was applied for water and filtrate, and toluol-POPOP-PPO cocktail for filters. Primary production of different fractions was calculated according to the standard formula (HELCOM, 1988). Non-photosynthetic carbon fixation was measured in dark vials and subtracted from light assimilation.

The acetylene reducion method (Stewart et al., 1967; Flett et al., 1976; Levine \& Schindler, 1992; Présing et al., 1996) was used to measure the molecular nitrogen fixation $\left(\mathrm{N}_{2}\right.$ fix) by cyanobacteria. Glass bottles of $60 \mathrm{~mL}$ were filled with lake water and exposed for $4 \mathrm{~h}$ in the incubator at constant illumination of $120 \mathrm{~W} \mathrm{~m}^{-2}$ and temperature adjusted to that of the lake surface. Measurements were made in the same days when water chemistry and Phy in the lakes were routinely monitored. In one measurement series three bottles were used. In one bottle $0.1 \mathrm{~mL}$ of $50 \% 3$-chloro-acetic acid (TCA) solution was added as an inhibitor to detect possible nonbiotic $\mathrm{N}_{2}$ fix. Two parallels were used to measure biotic $\mathrm{N}_{2}$ fix by adding a gas phase $(10.05 \mathrm{~mL})$ consisting of $2 \mathrm{~mL}$ of air, $8 \mathrm{~mL}$ of argon, and $0.05 \mathrm{~mL}$ of acetylene into the bottles with $49.95 \mathrm{~mL}$ lake water. Reaction was stopped by adding $0.1 \mathrm{~mL}$ of $50 \%$ TCA solution. The $\mathrm{N}_{2}$ fix activity was determined by analysing $2 \mathrm{~mL}$ of gas from each bottle by a gas chromatograph "Chrom 5" (Czechoslovakia) with a flame ionization detector and $220 \mathrm{~cm}$ Porapak R 80/100 column (Ø $3 \mathrm{~mm})$.

\section{Bacterioplankton and picoplankton}

The total number of bacteria (TNB) was determined by 4',6'-diamidino-2phenylindole (DAPI; Polysciences Inc; Porter \& Feig, 1980). Formaldehyde preserved subsamples were incubated with DAPI (final concentration $10 \mu \mathrm{g} \mathrm{mL}^{-1}$ ) for $5 \mathrm{~min}$ in the dark and filtered onto black $0.22-\mu \mathrm{m}$-pore-size polycarbonate filters (Osmonics Inc.). The abundance of autotrophic picoplankton (APP) was estimated by autofluorescence on the same filters as heterotrophic bacteria. All microscope observations were made at $\times 1000$ magnification with an epifluorescence microscope Zeiss Axiovert S100 as soon as possible; slides were stored at $-21^{\circ} \mathrm{C}$ if necessary.

Bacterial production (BP) was estimated by the tritiated thymidine incorporation method. Five samples ( +5 formaldehyde killed blanks), $10 \mathrm{~mL}$ each, were treated with different amounts of $\left[{ }^{3} \mathrm{H}\right]$ thymidine $(20-900 \mathrm{nM}$ : specific activity $5.0 \mathrm{Ci} \mathrm{mmol}^{-1}$; Amersham). After $30 \mathrm{~min}$ incubation at in situ temperature cold base-acid-ethanol extraction was used for purification of DNA as described by Wicks \& Robarts (1987). The cellulose acetate filters (pore size $0.22 \mu \mathrm{m}$; Millipore) 
were dissolved in Ecolume liquid scintillation cocktail, and radioactivity was measured by liquid scintillation counting (LSC RackBeta 1211, LKBWallac). The uptake of thymidine was converted to the number of produced cells by using the conversion factor $3.4 \times 10^{18}$ (Kisand \& Nõges, 1998).

\section{Metazooplankton}

All analyses were made from depth-integrated water taken from five sampling points from the lake centre to the shore and mixed together. Only in the central part of L. Vortsjärv the sample was collected from a single sampling point. Metazooplankton (MZP) was collected by filtering $10 \mathrm{~L}$ integrated lake water through a plankton net $(48 \mu \mathrm{m})$, fixed with Lugol's solution, and counted in three $2.5-5 \mathrm{~mL}$ subsamples. The samples were counted under a binocular microscope (MBC-9) in a Bogorov chamber and enumerated at $\times 32-56$ magnification. The individual weights of zooplankters were estimated from average lengths according to Ruttner-Kolisko (1977) and Balushkina \& Winberg (1979).

The samples of chydorids were collected from lakes Kaiavere, Suurlaht, Prossa, Uljaste, Mustjärv, and Võrtsjärv in August 2000. In 2001 the seasonal dynamics of chydorids of L. Prossa was studied. Five replicate samples were taken from the vegetation-free zone and from the zone with macrophytes. Samples were collected using a $100 \mu \mathrm{m}$ mesh net. Due to great variability, all five replicate samples were counted.

The grazing of MZP was measured by in situ feeding experiments with two different methods using fluorescent microspheres (FMS) in lakes Kaiavere and Võrtsjärv in 2000 and ${ }^{14} \mathrm{C}$-labelled Phy culture in L. Prossa in 2001. For grazing experiments with FMS the number of Phy cells $(<31.0 \mu \mathrm{m})$, presumably edible for MZP, was counted separately. Size classes were split by the maximum linear length: $2.0-4.9 \mu \mathrm{m}$ as the first, $5.0-14.9 \mu \mathrm{m}$ as the second, and $15.0-31.0 \mu \mathrm{m}$ as the third size class (SC1, SC2, and $\mathrm{SC} 3$, respectively). For bacteria FMS of $0.5 \mu \mathrm{m}$ diameter (Fluoresbrite, Polysciences Inc.) and for Phy of $3 \mu \mathrm{m}, 6 \mu \mathrm{m}$, and $24 \mu \mathrm{m}$ diameter (Duke Scientific Corporation) were used. The tracer amount that did not exceed $10 \%$ of the density of the corresponding size groups in lake water was added to integrated lake water in a 3-litre incubation vessel. Incubations lasted for $7 \mathrm{~min}$, after which the water was filtered through a plankton net $(48 \mu \mathrm{m})$, anaesthetized with carbonated water, and fixed in $4 \%$ formaldehyde. For FMS counting, individual zooplankters were collected from the samples and filtered onto a polycarbonate filter of $10 \mu \mathrm{m}$ pore size (Poretics). The number of FMS in the zooplankters' guts was counted at $\times 1000$ using an epifluorescence microscope (Zeiss Axiovert S100). The filtration (FR; $\mu \mathrm{L}_{\text {ind. }}{ }^{-1} \mathrm{~h}^{-1}$ ) and ingestion (IR; bacteria ind.$^{-1} \mathrm{~h}^{-1}$ ) rates for each taxon and community filtration (CFR; $\mathrm{mL} \mathrm{L}^{-1} \mathrm{~d}^{-1}$ ) and ingestion (CIR; cells $\mathrm{L}^{-1} \mathrm{~h}^{-1}$ ) rates were calculated using standard equations. The individuals that had empty guts were included. 
To assess zooplankton (ZP) community grazing by radioactively labelled Phy, $50 \mathrm{~mL}$ of Scenedesmus brasiliensis Bohlin monoculture (cell size 2.5-4 $\mu \mathrm{m}$ ) was labelled with $\mathrm{NaH}^{14} \mathrm{CO}_{3}$ during $36 \mathrm{~h}$ at $120 \mathrm{~W} \mathrm{~m}^{-2}$. Then cells were centrifuged at $3000 \mathrm{rpm}$, washed with filtered lake water (Whatman GF/C), and suspended in the same solution. The final amount of the algal suspension was $30 \mathrm{~mL}$. Of this suspension $10 \mathrm{~mL}$ was added into $4 \mathrm{~L}$ of integral lake water and incubated in the lake for $7 \mathrm{~min}$. In the experimental vessels the concentration of the labelled $S$. brasiliensis monoculture did not exceed $5-10 \%$ of the total suspended solid concentration of lake water $\left(1.0-5.5 \mathrm{mg} \mathrm{DW} \mathrm{L}^{-1}\right)$. After incubation, the water was filtered through a plankton net (mesh size $100 \mu \mathrm{m}$ ) to collect the ZP. The obtained filtrate was filtered through $48 \mu \mathrm{m}$ mesh to obtain the fraction of smaller ZP $(48-100 \mu \mathrm{m})$. The filtered ZP were anaesthetized with carbonated water and stored on ice. To measure the radioactivity of food, $30 \mathrm{~mL}$ of filtrate was retained on the $\mathrm{GF} / \mathrm{C}$ filters. In laboratory ZP were washed from the net to the GF/C filters. The radioactivity of the filters with $\mathrm{ZP}$ and food particles was measured by a liquid scintillation counter RackBeta 1211 (LKB Wallac). One measurement series consisted of three replicates. The $\mathrm{ZP}$ community filtration rate $\left(\mathrm{F}, \mathrm{mL} \mathrm{L}^{-1} \mathrm{~h}^{-1}\right)$ was calculated according to the formulae developed by Lampert \& Taylor (1985). Grazing rate $\left(\mathrm{G}, \mathrm{mg} \mathrm{L}^{-1} \mathrm{~h}^{-1}\right)$, relative grazing rate of Phy biomass $\left(\mathrm{RGR}_{\mathrm{b}}, \% \mathrm{~d}^{-1}\right)$, and relative grazing rate of primary production $\left(\mathrm{RGR}_{\mathrm{pp}}, \% \mathrm{~d}^{-1}\right)$ were calculated using standard equations.

\section{Planktonic ciliates}

For ciliate counts $250 \mathrm{~mL}$ of integral lake water was collected and fixed with Lugol's solution ( $0.5 \%$ of final concentration). The ciliates' biomass and community composition were determined using the Utermöhl (1958) technique. Ciliates were usually identified to genus by consulting several works (e.g. Patterson \& Hedley, 1992; Foissner \& Berger, 1996). Biovolumes of all taxa were estimated and the specific gravity was assumed to be $1.0 \mathrm{~g} \mathrm{~mL}^{-1}$ (Finlay, 1982), so the biomass was expressed as wet weight (WW). For grazing experiments FMS were used and the same methods were applied as described above under the metazooplankton section in lakes Kaiavere, Prossa, and Võrtsjärv in 2000. Incubations lasted for $7 \mathrm{~min}$, after which the samples were fixed with buffered formalin ( $1 \%$ final concentration). The preserved samples were stained for $1-2$ min with DAPI at a final concentration of $2 \mu \mathrm{g} \mathrm{mL}^{-1}$ and gently filtered through $0.8-\mu \mathrm{m}$ pore-size black isopore (Poretics Inc.) filters. Protists and the contents of their food vacuoles were examined with an Olympus BX60 fluorescence microscope under $\times 1000$ using blue light $(470 / 505 \mathrm{~nm}, \mathrm{OG} 515)$. As much as possible, the dominant taxa of fluorescently stained ciliates were identified based on knowledge on the composition of parallel Lugol fixed samples. To estimate the total ciliate grazing rate, their uptake rates were multiplied by their total in situ abundances. 


\section{Macrophytes}

To estimate macrophyte abundances in lakes Kaiavere, Mustjärv, Prossa, Suurlaht, Uljaste, and Võrtsjärv the Percent Volume Infested (PVI) method (Canfield et al., 1984) was used. One radial transect per $100 \mathrm{~m}$ of lake shore up to a maximum of 20 transects per lake was selected. All species of submerged and floating-leaved plants were identified and distributed into the following categories: charophytes, isoetids, and floating-leaved and submerged macrophytes. In each sampling point the coverage of filamentous and thalloid algae was assessed using the following 3 categories: (a) very abundant ( $>50 \%$ coverage), (b) moderate (10-50\% coverage), (c) rare $(<10 \%$ coverage). In the case of emergent plants we determined the percentage of the lake colonized and identified the dominant species ( $>20 \%$ of the community). To assess macrophyte zones in lakes Mustjärv, Uljaste, and Võrtsjärv the weighting method was used - the different areas were copied to the map, cut out, and compared with the weight of the whole lake map. The macrophyte zones in the other lakes are relative.

\section{Epiphyton}

Five samples of dominant macrophytes and three samples of other plants were collected from all lakes. Plants were placed into glass vessels with $100 \mathrm{~mL}$ distilled water and shaken for $2 \mathrm{~min}$. Water was filtered through a $94 \mu \mathrm{m}$ net (2000) or sieved (2001) to avoid detritus from getting into the samples. Samples were preserved with Lugol's solution and algal communities were studied using an inverted microscope at $\times 400$ (Utermöhl, 1958). For chlorophyll measurements the samples were filtered through GF/C filters and analysed as in Jeffrey et al. (1997). Plants, which were free of epiphyton, were dried for $24 \mathrm{~h}\left(\right.$ at $\left.100^{\circ} \mathrm{C}\right)$ and then weighed. The chlorophyll amount was calculated for the dry weight of the plants. We compared epiphytic communities on dominant macrophytes and other plants in each lake. We also compared the epiphyton communities in similar plant species collected from the different lakes. The similarity of communities was assessed with Student's two-sided $t$-test.

\section{Fish}

The structure and relative composition of fish communities was investigated by Lundgren gillnets according to a protocol of fish of ECOFRAME program in August-September 2000. Each net was $42 \mathrm{~m}$ long, $1.5 \mathrm{~m}$ high, and consisted of 14 units of $3 \mathrm{~m}$ with different mesh sizes (from knot to knot) in the following order: $6.25,8,16.5,75,38,25,12.5,33,50,22,43,30,60$, and $10 \mathrm{~mm}$. In the littoral zone sinking nets and in the pelagial zone sinking and floating nets were used. The number of nets used depended on lake area. The sampling sites were 
selected randomly. The catch per unit effort (CPUE) per net for each species and two size groups $(<10 \mathrm{~cm}$ and $\geq 10 \mathrm{~cm})$ with $95 \%$ confidence limits was calculated. For most common species the length-weight relationship and also the average length and weight for fish $<10 \mathrm{~cm}$ and $\geq 10 \mathrm{~cm}$ were determined. For each species the fork length (from nose tip to tail cleft) was measured to the nearest lower mm and weight in $\mathrm{g}$ with an accuracy of $0.1 \mathrm{~g}$ for fish smaller than $10 \mathrm{~cm}$ and with an accuracy of $1 \mathrm{~g}$ for fish over $10 \mathrm{~cm}$ was found. The abundance of fish in different lakes was compared on the basis of the mean CPUE either in weight or in the numbers of captured individuals. To calculate the mean yield of fish per the whole lake, the area of the littoral zone was taken into account as follows: Suurlaht $100 \%$, Prossa $75 \%$, Mustjärv 50\%, Uljaste 25\%, Kaiavere 25\%, and Võrtsjärv 20\%.

\section{RESULTS}

\section{Water Chemistry, Secchi depth, chlorophyll, and primary production}

In the central part of L. Vorrtsjärv the $\mathrm{PO}_{4}-\mathrm{P}$ concentrations were high (up to $0.03 \mathrm{mgP} \mathrm{L}^{-1}$ ) in winter 2000 , but stayed low in summer. The TP range was from 0.034 to $0.07 \mathrm{mg} \mathrm{L}^{-1}$. The concentration of $\mathrm{NH}_{4}-\mathrm{N}$ dropped below $0.03 \mathrm{mg} \mathrm{L}^{-1}$ by the end of April. The concentration of $\mathrm{NO}_{2}-\mathrm{N}$ was $0.009-0.013 \mathrm{mgN} \mathrm{L}^{-1}$, and from $<0.002$ to $0.004 \mathrm{mgN} \mathrm{L}^{-1}$ in summer. Also the concentrations of $\mathrm{NO}_{3}-\mathrm{N}$ and $\mathrm{TN}$ were higher in winter than in summer.

In the southern part of L. Võrtsjärv the concentrations of $\mathrm{PO}_{4}-\mathrm{P}$ and $\mathrm{TP}$ (0.007-0.027 and $0.073-0.12 \mathrm{mg} \mathrm{L}^{-1}$, respectively) were higher than in the central part of L. Võrtsjärv as well as in other lakes during the ice-free period. Average concentrations of both $\mathrm{NH}_{4}-\mathrm{N}$ and $\mathrm{NO}_{2}-\mathrm{N}$ were low during the ice-free period (0.06 and $0.02 \mathrm{mg} \mathrm{L}^{-1}$, respectively). The concentration of $\mathrm{NO}_{3}-\mathrm{N}$ was still on its winter level $\left(0.97 \mathrm{mgN} \mathrm{L}^{-1}\right)$ after ice break in April, but dropped quickly below $0.05 \mathrm{mg} \mathrm{L}^{-1}$ at the beginning of May. The TN values were $1.7 \mathrm{mg} \mathrm{L}^{-1}$ in April, but remained thereafter around $1 \mathrm{mg} \mathrm{L}^{-1}$.

In L. Prossa TP was the lowest among the studied lakes: $\leq 0.035 \mathrm{mg} \mathrm{L}^{-1}$. Its level decreased after May and remained low until September. In 2001 TP was lower than in the previous year, especially in the first part of summer. Concentrations of inorganic nitrogen compounds, mostly $\mathrm{NO}_{3}-\mathrm{N}$, were high in April, but decreased sharply at the beginning of June.

In L. Kaiavere the organic compounds of phosphorus dominated during the ice-free period while $\mathrm{PO}_{4}-\mathrm{P}$ was usually lower than $0.005 \mathrm{mgP} \mathrm{L}^{-1}(<5 \%$ from $\mathrm{TP})$. The average TP was slightly lower in 2001 than in the previous year $(0.049$ and $0.055 \mathrm{mg} \mathrm{L}^{-1}$, respectively). The nitrogen dynamics (both TN and Nmin) of L. Kaiavere was similar to L. Prossa - a sharp decline occurred in May.

In both lakes Prossa and Kaiavere the Secchi depth (S) was quite high and chlorophyll $a$ concentration ( $\mathrm{Chl}$ a) and primary production (PP) were moderate in April after the ice break. From July L. Prossa developed into a typical clearwater 
macrophyte-dominated state $(\mathrm{S} \leq 4 \mathrm{~m})$ while $\mathrm{L}$. Kaiavere remained turbid and plankton-dominated with the water transparency about $1 \mathrm{~m}$ (Fig. 1). In L. Kaiavere also a second boost in Chl and PP occurred in autumn 2001, which was not observed in 2000 .
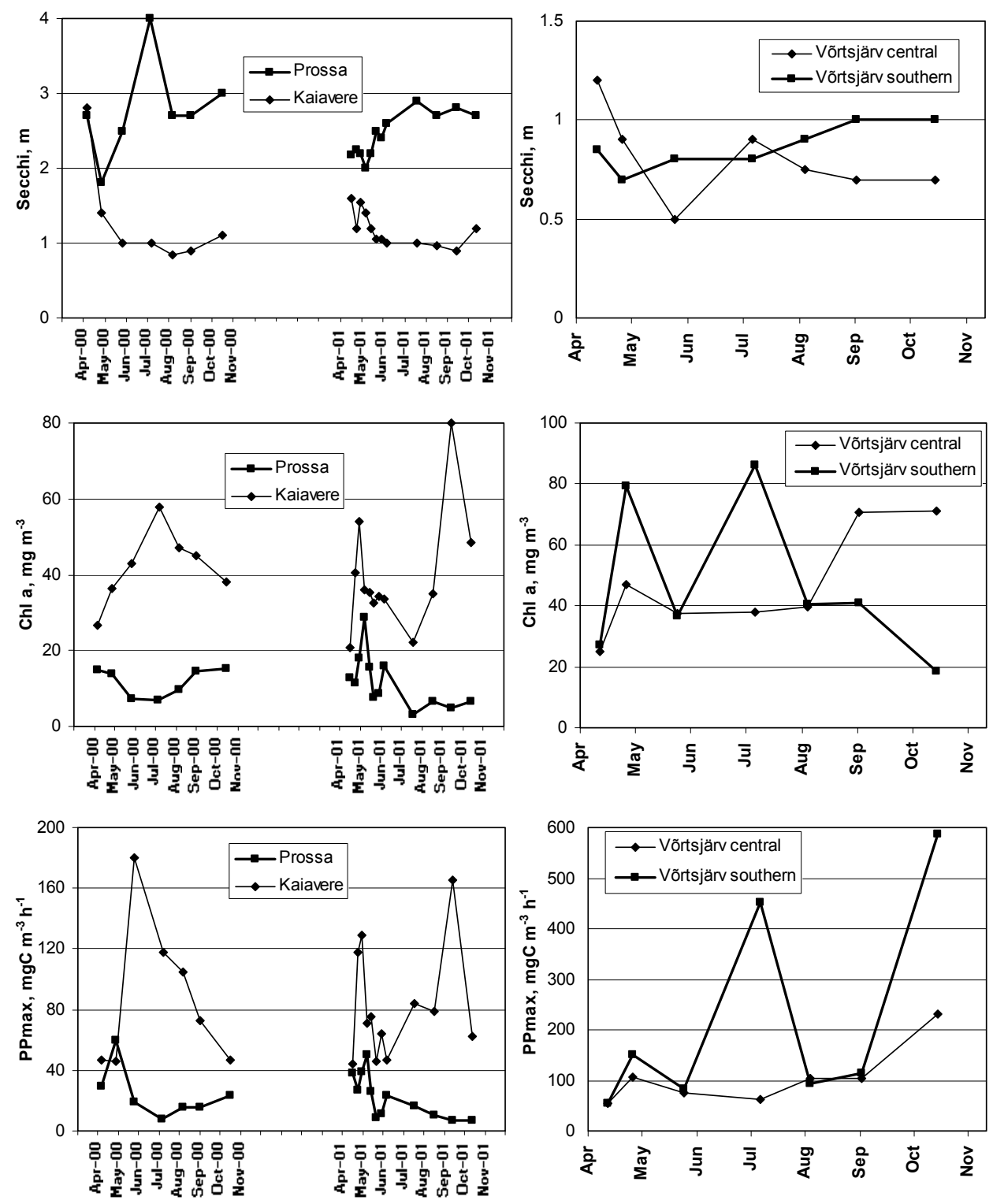

Fig. 1. Secchi depth, chlorophyll $a$, and primary production in lakes Kaiavere and Prossa (2000 and 2001) and in the central and southern parts of L. Võrtsjärv (2000). 
The central part of L. Võrtsjärv acted like a typical plankton lake. The southern part of the lake did not develop to a typical clearwater macrophyte-dominated state and harboured an abundant Phy community also in summer.

\section{Bacterioplankton and autotrophic picoplankton}

The abundance of bacteria in L. Kaiavere was $0.4-7.5 \times 10^{6}$ cells $\mathrm{mL}^{-1}$ (median 3.0), being higher than in L. Prossa $\left(0.7-4.1 \times 10^{6}\right.$ cells $\mathrm{mL}^{-1}$; median 2.0). In the central part of L. Võrtsjärv the abundance of bacteria (median $1.6 \times 10^{6}$ cells mL $\mathrm{mL}^{-1}$ ) was lower than in its southern part (median $2.3 \times 10^{6}$ cells $^{-1}$ ). In L. Kaiavere and in the central part of L. Vorrtsjärv the highest bacterial numbers were achieved in June. In L. Prossa and the southern part of L. Võrtsjärv the bacterial abundance peaked in July (in 2000) or May (in 2001 in L. Prossa). In the central part of L. Võrtsjärv (in 2000) the abundance of autotrophic picoplankton peaked in October, in its southern part in July and in L. Kaivere and in L. Prossa in June. Bacterial production (BP) rates were significantly higher in 2001 than in 2000. Also the difference in BP was more pronounced in L. Kaiavere and L. Prossa in 2001 than in 2000. In L. Kaiavere BP ranged during the study period from 3.5 to $254 \times 10^{6}$ cells $\mathrm{L}^{-1} \mathrm{~h}^{-1}$ (median 114) and in L. Prossa from 13 to $211 \times 10^{6}$ cells $\mathrm{L}^{-1} \mathrm{~h}^{-1}$ (median 103). In L. Kaiavere BP peaked in July in 2000 while in 2001 three BP peaks occurred, the highest at the end of May. In L. Prossa BP reached the highest values in July and August (in 2000 and 2001, respectively). In the central part of L. Võrtsjärv (in 2000) BP ranged from 3.8 to $165 \times 10^{6}$ cells $\mathrm{L}^{-1} \mathrm{~h}^{-1}$ (median 17) and in the southern part from 33 to $318 \times 10^{6}$ cells $\mathrm{L}^{-1} \mathrm{~h}^{-1}$ (median 94). During the study period, the highest production was measured in the central part of L. Võrtsjärv in June while the most pronounced maximum in the southern part was found in August.

\section{Metazooplankton}

In L. Prossa the MZP maximum was reached in May. The abundance and biomass were dominated by rotifers but in summer also cladocerans (Bosmina longirostris) and copepods (juveniles and Mesocyclops spp.) were abundant. The same pattern was observed in L. Kaiavere. From cladocerans Bosmina longirostris, B. coregoni, and Chydorous sphaericus were important in June and Daphnia cucculata in August. Copepods were dominated by Mesocyclops leuckarti and M. oithonoides. In L. Prossa the abundances of MZP were lower than in L. Kaiavere (Fig. 2). In L. Võrtsjärv's central part the zooplankton maximum was reached in July. The highest biomasses were measured at the end of May and in June. The abundance was dominated by rotifers (Keratella tecta, Anuraeopsis fissa) and the biomass by cladocerans (Bosmina longirostris, Chydorous sphaericus). 

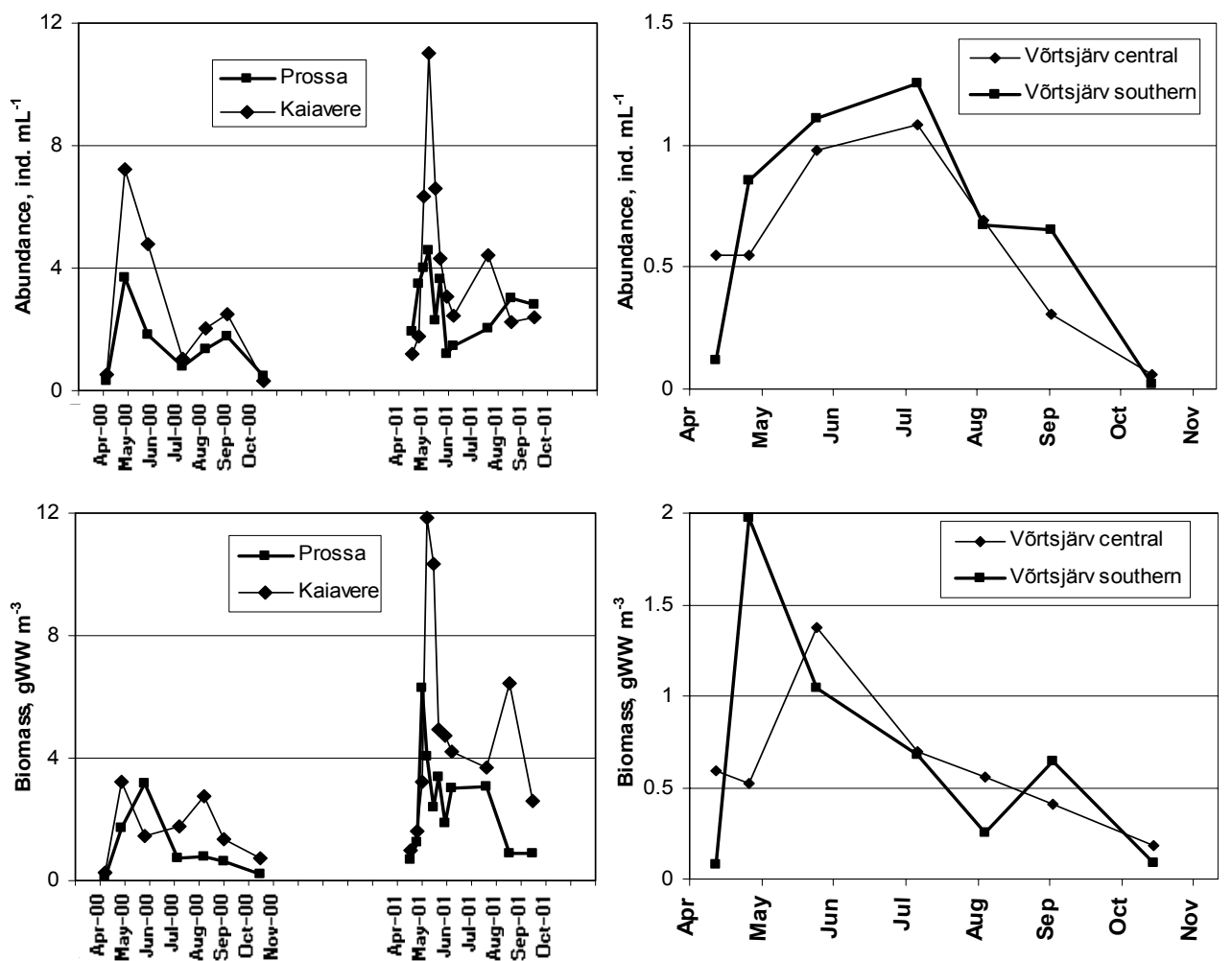

Fig. 2. Abundance and biomass of metazooplankton in lakes Kaiavere and Prossa (2000 and 2001) and in the central and southern parts of L. Võrtsjärv (2000).

Cladocerans peaked in June and copepods in May and July. During summer the number of small rotifers (Anuraeopsis fissa, Keratella tecta) increased. In L. Võrtsjärv's southern part the species composition, seasonal dynamics, and abundances were similar to those in the central part and the maximum abundance was reached in July (Fig. 2). Rotifers dominated both abundance and biomass. Cladocerans peaked in May and copepods in June.

In 2001 the abundance of chydorids in L. Prossa was low in April and May, but started to rise at the beginning of June and reached its maximum in July. Thereafter the abundance of chydorids dropped. The dominating chydorid species was Chydorous sphaericus.

\section{Planktonic ciliates}

In 2000 in L. Kaiavere the highest abundance and biomass of ciliates was achieved in late summer, while in 2001 the maximum biomass occurred during 
the spring peak of large-sized peritrichs, oligotrichs, and nassulids. In late summer the ciliate community was dominated by small-sized prostomatids but also scuticociliates and small oligotrichs (Fig. 3).

In 2001 in L. Prossa the highest abundance and biomass of ciliates was achieved in late spring, while in 2000 the biomass maximum occurred during late summer because of the occurrence of large-sized hymenostomatids. In spring the ciliate community was dominated mostly by large-sized oligotrichs. In summer these species were gradually replaced by small-sized prostomatids and oligotrichs but also the above-mentioned large hymenostomatids were important.

In L. Võrtsjärv's central part the ciliate abundance and biomass peaked in spring and in late summer. The highest abundance was achieved in July and the highest biomass in May. In L. Võrtsjärv's southern part the seasonal dynamics of ciliates was similar to that in the central part, but the maximum biomass coincided with the maximum abundance in July (Fig. 3). The main difference between the two sites was in the community structure. In both locations large-sized herbivorous
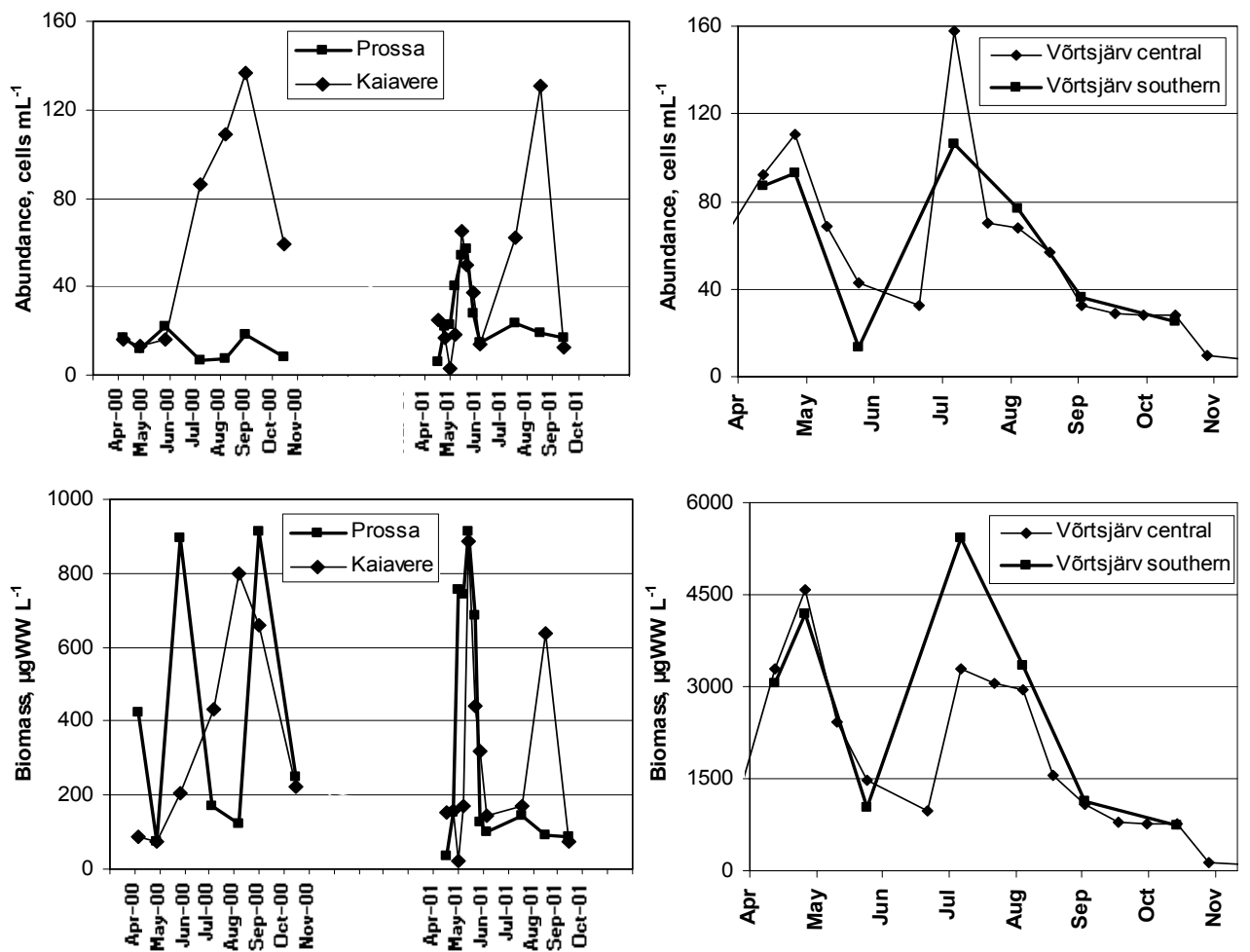

Fig. 3. Abundance and biomass of planktonic ciliates in lakes Kaiavere and Prossa (2000 and 2001) and in the central and southern parts of L. Võrtsjärv (2000). 
oligotrichs made up the spring peak. The summer peak in the central part consisted mainly of small bacterivorous species but in the lake's southern part large-sized herbivores were still more numerous than small bacterivores.

\section{Ciliate and metazooplankton grazing}

Ciliate grazing rates upon bacteria were highest in L. Kaiavere (Table 3) and in the central part of L. Võrtsjärv (Fig. 4). Grazing rates upon algae were highest in L. Prossa and in L. Võrtsjärv's southern part. In all the studied lakes MZP showed the highest grazing rates on bacteria-sized FMS (Table 4). The highest grazing rates upon bacteria were found in June (Fig. 5). The most intense MZP grazing on algae was found in L. Kaiavere with the maximum in June. In L. Võrtsjärv the highest values were recorded in August (central part) and in May (southern) (Fig. 6).

The grazing experiments in 2001 in L. Prossa showed that zooplankters larger than $100 \mu \mathrm{m}$ (cladocerans, copepods, and larger rotifers) achieved their maximum filtering rate of $12.7 \mathrm{~mL} \mathrm{~L}^{-1} \mathrm{~h}^{-1}$ in June (Fig. 7). The highest abundance of cladocerans, copepods, and large $(>100 \mu \mathrm{m})$ rotifers occurred in May, but the filtering rate $\left(6.6 \mathrm{~mL} \mathrm{~L}^{-1} \mathrm{~h}^{-1}\right)$ was not the highest at that time.

Table 3. The mean grazing rates of planktonic ciliates in the studied shallow lakes

\begin{tabular}{|c|c|c|}
\hline \multirow[t]{2}{*}{ Lake } & \multicolumn{2}{|c|}{ Mean grazing rate } \\
\hline & $\begin{array}{c}\text { Bacteria }(0.5 \mu \mathrm{m}) \\
\mathrm{mL}^{-1} \mathrm{~h}^{-1}\end{array}$ & $\begin{array}{c}\text { Algae }(3 \mu \mathrm{m}), \\
\mathrm{L}^{-1} \mathrm{~h}^{-1}\end{array}$ \\
\hline Võrtsjärv central & 20334 & 50996 \\
\hline Võrtsjärv southern & 13989 & 87274 \\
\hline Kaiavere & 27850 & 18633 \\
\hline Prossa 2000 & 8226 & 145849 \\
\hline Prossa 2001 & 8105 & 186388 \\
\hline
\end{tabular}

Table 4. The mean grazing rates of metazooplankton in the studied shallow lakes

\begin{tabular}{l|c|c|c|c}
\hline \multirow{2}{*}{ Lake } & \multicolumn{4}{|c}{ Mean grazing rate } \\
\cline { 2 - 5 } & $\begin{array}{c}\text { Bacteria } \\
(0.5 \mu \mathrm{m}), \\
\mathrm{mL}^{-1} \mathrm{~h}^{-1}\end{array}$ & $\begin{array}{c}\text { Algae } \\
(2-5 \mu \mathrm{m}), \\
\mathrm{L}^{-1} \mathrm{~h}^{-1}\end{array}$ & $\begin{array}{c}\text { Algae } \\
(5-15 \mu \mathrm{m}), \\
\mathrm{L}^{-1} \mathrm{~h}^{-1}\end{array}$ & $\begin{array}{c}\text { Algae } \\
(15-31 \mu \mathrm{m}), \\
\mathrm{L}^{-1} \mathrm{~h}^{-1}\end{array}$ \\
\hline Võrtsjärv central & 174 & 1151 & 541 & - \\
Võrtsjärv southern & 165 & 784 & 501 & - \\
Kaiavere & 907 & 9697 & 3400 & 89
\end{tabular}



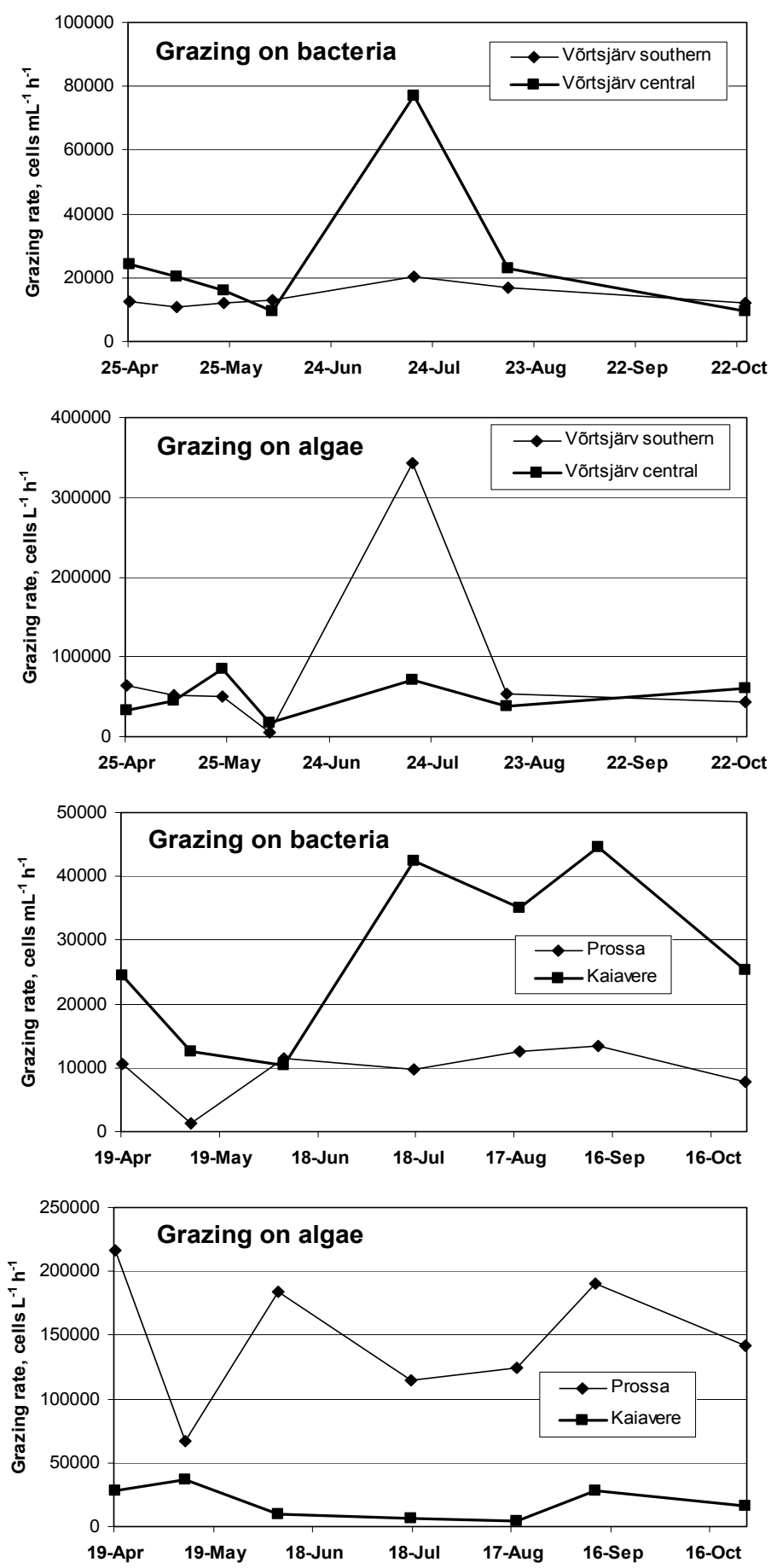

Fig. 4. Ciliate grazing on bacteria and algae in the central and southern parts of L. Võrtsjärv and in lakes Kaiavere and Prossa in 2000. 

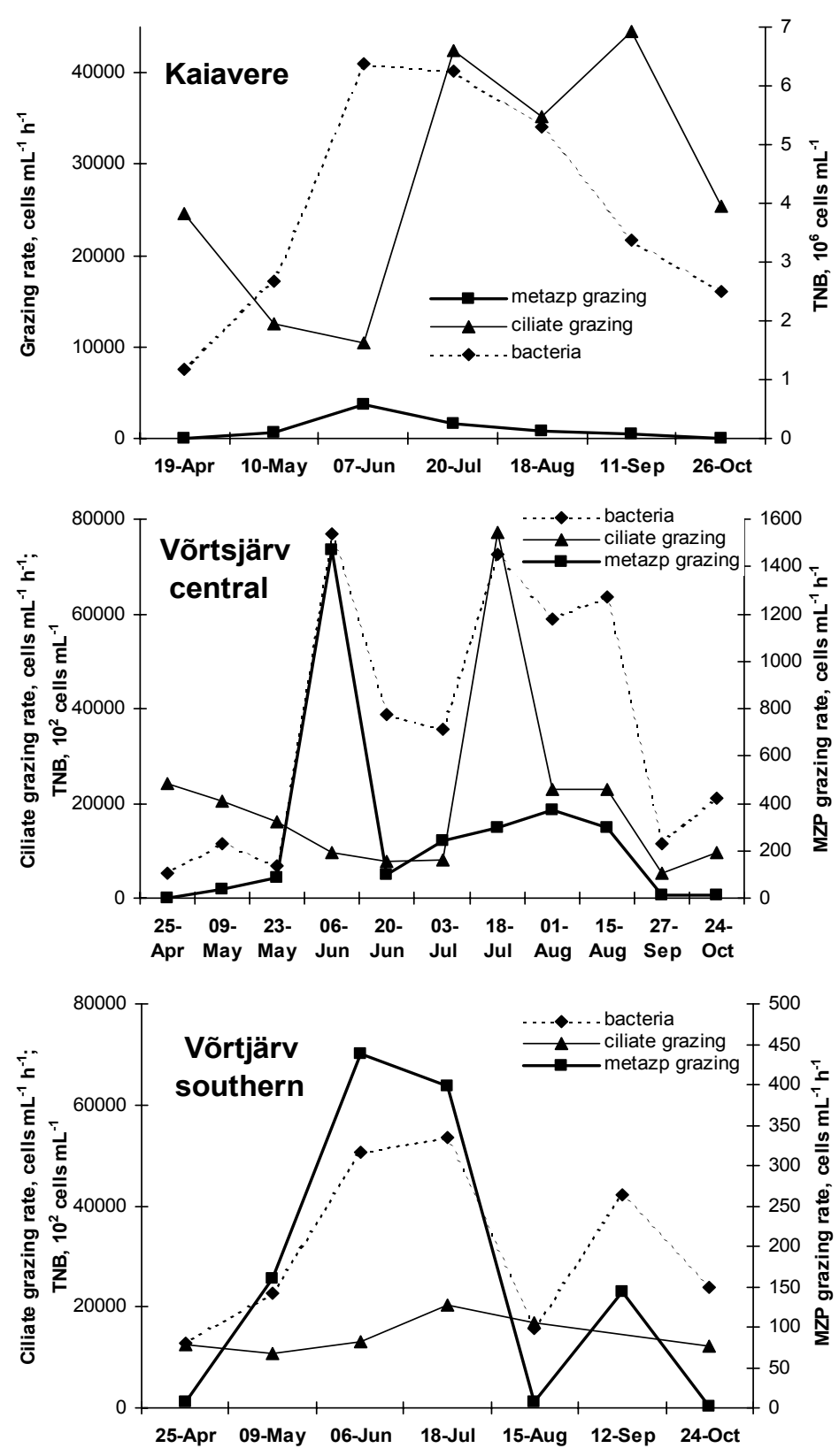

Fig. 5. Ciliate and metazooplankton grazing on bacteria and bacterial abundance in L. Kaiavere and in the central and southern parts of L. Vorrtsjärv in 2000. 

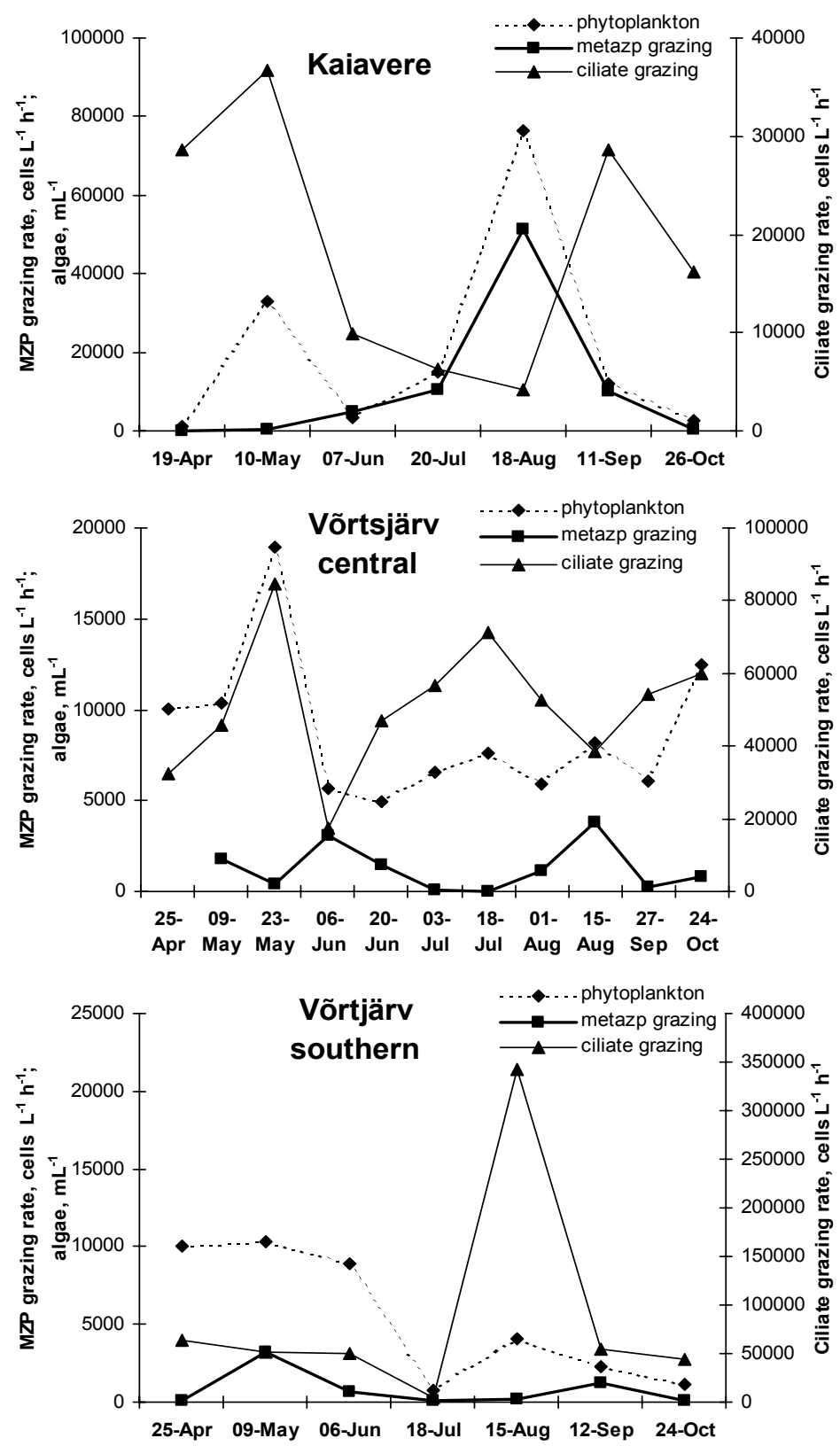

Fig. 6. Ciliate and metazooplankton grazing on small algae $(\varnothing \sim 3 \mu \mathrm{m})$ and abundance of small algae in L. Kaiavere and in the central and southern parts of L. Võrtsjärv in 2000. 


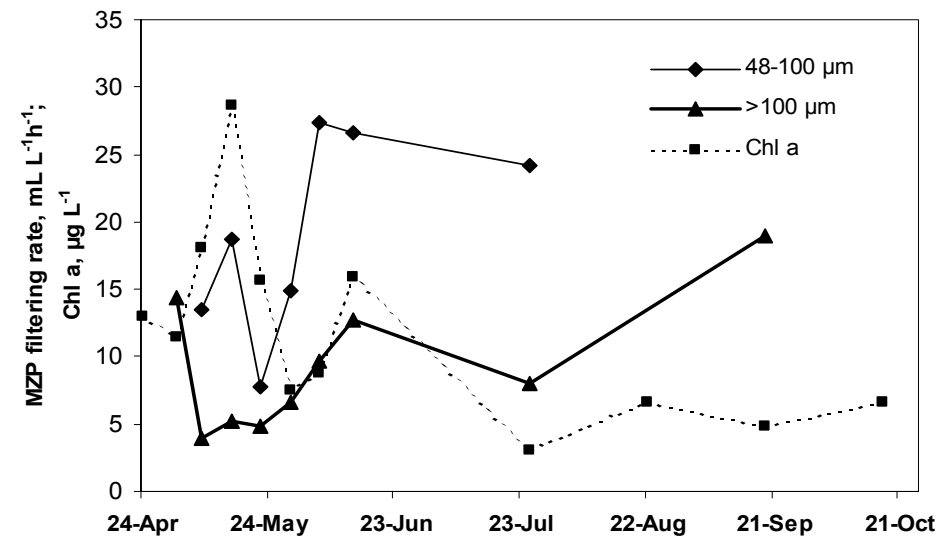

Fig. 7. Filtering rates of different metazooplankton size groups and chlorophyll $a$ in L. Prossa in 2001.

\section{Phytoplankton and molecular nitrogen fixation}

In the central part of L. Võrtsjärv the Phy biomass reached its maximum in spring. In summer the biomass decreased but peaked again in autumn (Fig. 8). The Phy was dominated by blue-greens and diatoms. Most common blue-greens were Limnothrix redekei, L. planktonica, and Aphanizomenon skujae and the most common diatoms Melosira spp. and Synedra acus. The biomass of other Phy groups such as chlorophytes, chrysophytes, and dinophytes was low. In the southern part of L. Võrtsjärv the biomass values stayed lower than in the central part, and the maximum biomass was achieved in summer. The biomass peaked also in spring. In spring the Phy community was dominated by blue-greens but in summer by diatoms.

In L. Prossa the maximum Phy biomass was achieved in spring, but in summer and in autumn the biomass stayed at a very low level (Fig. 8). The Phy was dominated by chrysophytes (Chrysophyceae) and cryptophytes (Cryptophyta). In 2000 cryptophytes were the most important while in 2001 the crysophytes were predominant. The most abundant chrysophyte species in spring were Dinobryon divergens and $D$. sociale var., while in summer and in autumn the most abundant was Uroglena sp. In spring also diatoms (Synedra ulna, S. acus, Melosira sp.) were numerous.

In L. Kaiavere the Phy biomass was low in spring and reached its maximum during late summer or early autumn (Fig. 8). In spring the dominating Phy group was diatoms (Melosira sp., Synedra ulna, and S. acus). Blue-greens (Aphanizomenon sp., Pseudanabaena calenata, Oscillatoria lauterbornii, Microcystis pulverea, and Aphanothece clathrata) were the most important group in summer and autumn. In autumn, during the second peak of diatoms, the dominating species were Acanthoceros sp., Fragilaria crotonensis, and Melosira sp. Chlorophytes (Scenedesmus sp., Pediastrum sp., Monoraphidium sp.), chrysophytes 

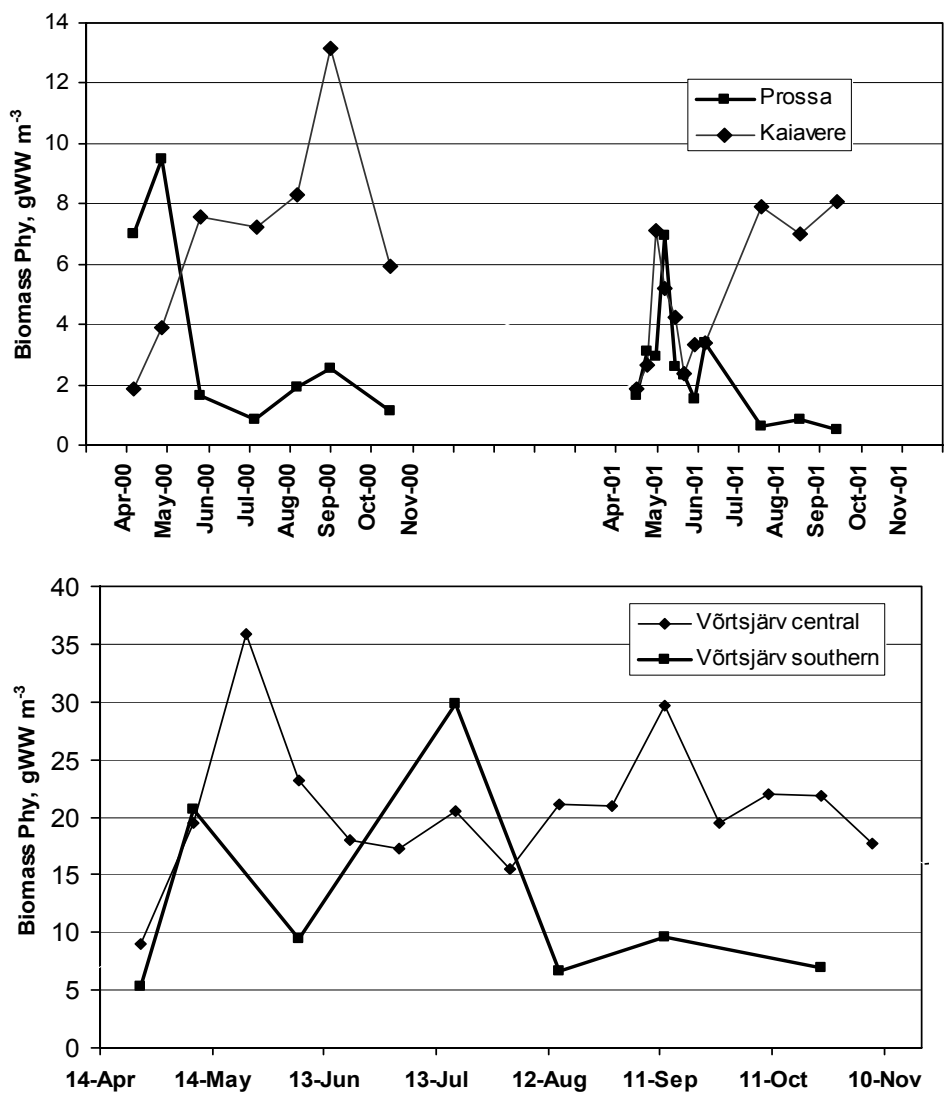

Fig. 8. Phytoplankton biomass in lakes Kaiavere and Prossa in 2000 and 2001 and in the central and southern parts of L. Võrtsjärv in 2000.

(Dinobryon sp., Uroglena sp.), cryptophytes, dinophytes, and euglenophytes were present but they were less important than blue-greens and diatoms. In the central part of L. Võrtsjärv $\mathrm{N}_{2}$ fixation $\left(\mathrm{N}_{2} \mathrm{fix}\right)$ was detected in August and September 2000. The highest $\mathrm{N}_{2}$ fix values were recorded in August $\left(2.5 \mu \mathrm{gN} \mathrm{L}^{-1}\right.$ day $\left.^{-1}\right)$. In the southern part no $\mathrm{N}_{2}$ fix was detected. In L. Kaiavere $\mathrm{N}_{2}$ fix was low $\left(\max 0.95 \mu \mathrm{gN} \mathrm{L}^{-1}\right.$ day $^{-1}$ ) in September 2000. In L. Prossa no $\mathrm{N}_{2}$ fix was detected.

\section{Macrophytes and epiphyton}

The number of macrophyte species, percent volume infested (PVI), and the coverage of filamentous algae are given in Table 5. The area of water plant zones and dominant species in the zone of emergent plants are given in Table 6. In three lakes (Kaiavere, Prossa, and Võrtsjärv) the number of macrophyte species was 
Table 5. Coverage of the studied lakes by aquatic plants, number of species, and percent volume infested (PVI)

\begin{tabular}{l|c|c|l|c|c|c}
\hline \multicolumn{1}{c}{ Lake } & $\begin{array}{c}\text { Lake area } \\
\text { occupied } \\
\text { by plants, } \\
\%\end{array}$ & $\begin{array}{c}\text { Shoreline plants } \\
\text { from the plant } \\
\text { occupied area, } \\
\%\end{array}$ & $\begin{array}{c}\text { Dominating species } \\
\text { of shoreline plants }\end{array}$ & $\begin{array}{c}\text { Number } \\
\text { of } \\
\text { species }\end{array}$ & $\begin{array}{c}\text { PVI, } \\
\%\end{array}$ & $\begin{array}{c}\text { Coverage of } \\
\text { filamentous } \\
\text { and thalloid } \\
\text { algae }\end{array}$ \\
\hline Prossa & 100 & 10 & Typha angustifolia & 19 & 41.21 Moderate \\
Kaiavere & 33.6 & 10 & Schoenoplectus lacustris & 17 & 3.8 Moderate \\
Võrtsjärv & 18.8 & 4.6 & Phragmites australis & 21 & 1.68 Moderate \\
Suurlaht & 100 & 10 & Phragmites australis & 7 & 6.81 Very abundant \\
Uljaste & 6.63 & 1.02 & Phragmites australis & 12 & 0.99 Moderate \\
Mustjärv & 36.73 & 6.63 & Zizania aquatica & 9 & 13.16 Moderate
\end{tabular}

Table 6. Proportion of the area of water plant zones and dominant species in the emergent plant zone in the studied shallow lakes $(\mathrm{EP}=$ emergent plant area, $\mathrm{FP}=$ floating-leaved plant area, $\mathrm{SP}=$ submerged plant area, $\mathrm{TP}=$ total plant area) and epiphyton communities in the studied lakes in 2000. Significance of differences $(p)$ between epiphytic communities on different plants (Plant) in each lake and similarity of communities in similar plant species, collected from different lakes (\%)

\begin{tabular}{|c|c|c|c|c|c|c|c|}
\hline Lake & $\begin{array}{c}\mathrm{EP}, \\
\%\end{array}$ & Dominant species & $\begin{array}{c}\text { FP \& } \\
\text { SP, } \\
\%\end{array}$ & $\begin{array}{l}\mathrm{TP}, \\
\%\end{array}$ & $p$ & Plant & $\%$ \\
\hline Prossa & 10 & Typha angustifolia & 90 & 100 & 0.004 & Typha latipholia & 20 \\
\hline Kaiavere & 10 & Schoenoplectus lacustris & 23.6 & 33.6 & 0.8521 & No data & \\
\hline Võrtsjärv & 4.6 & Phragmites australis & 14.2 & 18.8 & 0.001 & Chara sp. & 48 \\
\hline Suurlaht & 10 & Phragmites australis & 90 & 100 & 0.0001 & Nuphar lutea & 10 \\
\hline Uljaste & 1.02 & Phragmites australis & 5.61 & 6.63 & 0.0001 & $\begin{array}{c}\text { Phragmites } \\
\text { australis }\end{array}$ & 30 \\
\hline Mustjärv & 6.63 & Zizania aquatica & 23.98 & 36.73 & 0.008 & Potamogeton lucens & 40 \\
\hline
\end{tabular}

similar. According to the PVI and plant distribution area in L. Prossa submerged macrophytes (mostly Chara) grew in very dense mats on the bottom (PVI $41.2 \%$ ). In L. Suurlaht submerged macrophytes were distributed in a comparable area (Chara being dominant again) but they were growing only in thin mats (PVI 6.8\%). The epiphyton data gathered in 2000 are given in Table 6.

\section{Fish}

The fish community was most abundant in L. Võrtsjärv (Fig. 9), with eleven fish species captured. The abundance and variety of species differed greatly between the littoral and pelagic zones; however, the most abundant and evenspread species was roach followed by perch, bream flat, pike, and bleak. A mean littoral haul of $4 \mathrm{~kg}$ appeared to be multifold as compared to other lakes. The 


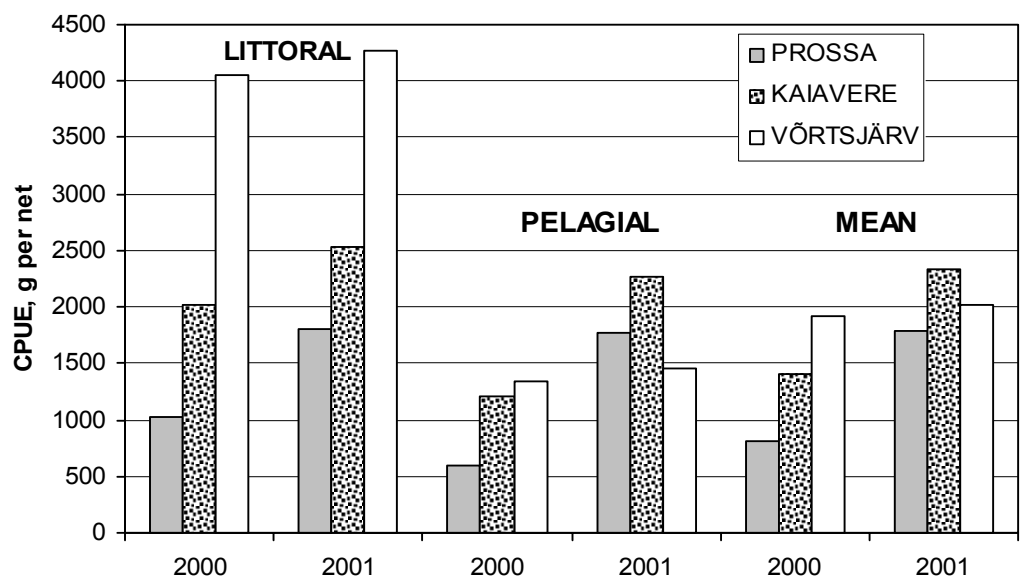

Fig. 9. Catch per unit effort (CPUE) per net in lakes Prossa, Kaiavere, and Võrtsjärv in 2000 and 2001.

pelagic zone with the mean haul of less than $1.5 \mathrm{~kg}$ was rich in smelt, bleak, ruff, and pikeperch. The littoral zone of L. Võrtsjärv was extremely rich in fishes of young age-groups.

In L. Kaiavere seven fish species were hauled with roach the most frequent and bleak, bream, and perch at heel. Of valuable fish species pike and pikeperch were abundant. The generic mean biomass of fish exceeded significantly that of the other small lakes. The mean CPUE of L. Kaiavere was $1407 \mathrm{~g}$ with $2018 \mathrm{~g}$ in the littoral and $1205 \mathrm{~g}$ in the pelagic zone. As compared to other lakes, juveniles make up a relatively greater fraction in L. Kaiavere.

Lake Prossa is poorer both in variety and abundance of fish as compared to the other studied lakes in the region. The dominant fish species were roach and perch, whereas pike and crucian carp were less frequent. The mean CPUE slightly exceeded $900 \mathrm{~g}$.

\section{DISCUSSION}

The TN/TP mass ratio in L. Kaiavere (20-30) and especially in L. Prossa (34-45) indicates that in these lakes it is phosphorus rather than nitrogen that controls the development of Phy during the summer. Increased resuspension due to the scarcity of submerged macrophytes resulted in generally higher concentrations of total nutrients and suspended solids in L. Kaiavere. The high N/P ratio and the low phosphorus concentration in L. Kaiavere probably hindered $\mathrm{N}_{2}$ fix, as bluegreens with $\mathrm{N}_{2}$ fix ability were abundant already in August 2000, but $\mathrm{N}_{2}$ fix occurred only in September. It is known from the literature (Levine \& Schindler, 1999; Smith \& Bennett, 1999; Hambright et al., 2001) that nitrogen fixing cyanobacteria prefer a low $\mathrm{N} / \mathrm{P}$ ratio. 
The peak in soluble reactive phosphorus (SRP) in L. Prossa could probably be attributed to a release from redox-sensitive fractions in anoxic conditions often formed on the sediment surface beneath dense Chara beds. Still the peak was not very large and as there are limits to very precise determination of SRP, it can also be an artifact of determination.

The abundance of bacteria was higher in plankton-dominated L. Kaiavere than in L. Prossa. In L. Kaiavere the high fluctuation in bacterial abundance and production in spring 2001 was probably related to the development of Phy. Another possible explanation is competition for P. High bacterial production rates in late summer 2001 indicate availability of nutrients. However, the abundance of bacteria was low presumably because of high ciliate pressure. In L. Prossa the development of bacteria seemed to be associated to PP only in spring when macrophytes were not dominant. Differently from L. Kaiavere, the grazing of ciliates in macrophytedominated L. Prossa has no limiting effect on bacterial abundance.

In the southern part of L. Vortsjärv, the influx of the nutrients via the VäikeEmajõgi River is the highest, e.g. in 1996 the TP and TN loading of this river made up $48 \%$ and $40 \%$ of the total load to the lake, respectively (Bilaletdin et al., 1998). Such a strong nutrient load supported the development of Phy, and the macrophytes could not act as really important competitors for nutrients in the water column. The increased PP and Chl a in the southern area (but also in the central part) seems to be a result of increased nutrient concentrations $\left(\mathrm{PO}_{4}-\mathrm{P}\right.$ in May and Nmin in July). It seems that nutrients do not limit the Phy development in the southern part as their concentrations were never very low there. The sharp decrease in Chl a concentrations in June could be due to zooplankton grazing.

The Phy biomass maximum in L. Võrtsjärv in spring is rather typical of macrophyte-dominated lakes. As the summer biomass values also stayed high and the clearwater period was not detected, we can say that the lake's central part acted like a plankton-dominated lake. High summer values were probably supported by the nutrient influx via the Väike-Emajõgi River. Also the powerful upward flux of nutrients in the lake, caused mainly by resuspension (Nõges et al., 1998), could enhance Phy growth. In the central part of L. Võrtsjärv $\mathrm{N}_{2}$ fix started when the TN/TP mass ratio was 20 (Tõnno \& Nõges, 2003), this is much higher than the Redfield mass ratio 7 (Howarth et al., 1988). As the symptoms of N-limitation in L. Võrtsjärv's central part caused by the TN/TP ratio are greater than predicted by the Redfield ratio, we assumed the recycling rate of $\mathrm{P}$ to be higher than that of $\mathrm{N}$ and consequently the ratio of the recycled $\mathrm{N}$ to recycled $\mathrm{P}$ was lower than TN/TP.

Similarly to Phy, the high abundance and production of bacteria in the southern part of L. Võrtsjärv were to a large extent supported by the influx of nutrients via the Väike-Emajõgi River. Despite the high PP and Phy biomass, bacteria were not found to rely on Phy as a source of organic carbon as noted over various aquatic systems (e.g. Cole et al., 1988; Ducklow \& Carlson, 1992). This decoupling may be a result of a time-lag in the response of bacteria to primary production, because the majority of organic matter fixed by Phy becomes available to bacteria after a crash in Phy biomass due to various biological processes (e.g. grazing). The ciliate 
grazing pressure on bacteria was low in the southern part compared to the central part of L. Võrtsjärv. Only in August, despite a high production, bacterial abundance remained low in the southern part of the lake, indicating an increased grazing pressure on bacteria.

The highest bacterial production and abundance in the central part of L. Vorrtsjärv were achieved in June when the grazing pressure of ciliates was low because of the dominance of herbivorous species. The production of bacteria did not seem to be limited by the availability of nutrients and was related to Phy production. The substantial decrease in bacterial abundance and production in July coincided with a peak in ciliate abundance suggesting that top-down regulation of bacterioplankton development is significant. From previous observations it is known that ciliate grazing can exceed bacterial production in the central part of L. Võrtsjärv (Kisand \& Zingel, 2000).

The increased grazing by pelagic zooplankton hiding in macrophytes during daytime (Timms \& Moss, 1984; Søndergaard \& Moss, 1998), as well as the grazing by macrophyte-associated zooplankton species (Lauridsen \& Buenk, 1996), has been often considered among the most important factors controlling Phy biomass in macrophyte-dominated lakes. However, our case study showed that the MZP abundances were even slightly higher in plankton-dominated lakes. Due to that the observed differences in Phy biomass are hard to explain by differences in MZP grazing intensities.

The community of chydorids was most diverse in the littoral zones of macrophyte-dominated lakes. In the pelagial the chydorids were absent or represented only by one species. The mean abundance of chydorids was the highest in the littoral macrophyte habitat. There was no difference between the chydorids' mean abundances in the littoral biotopes without macrophytes and the pelagial. The higher abundance of chydorids in all biotopes in macrophyte-dominated lakes was due to the presence of several well-adapted chydorid species.

The highest abundances of planktonic ciliates were found in the central part of L. Võrtsjärv and in L. Kaiavere, i.e. in the plankton-dominated lakes, but the highest biomasses were found in the macrophyte-dominated ones. Ciliates' biomass was moderate compared with MZP in lakes Kaiavere and Prossa. It was only in L. Võrtsjärv that ciliates formed a significant part of the total zooplankton biomass.

In all studied lakes ciliates had a clear spring peak dominated by larger herbivorous ciliates, followed by a decrease and a second peak later in summer formed mostly by small bacterivores (in the plankton-dominated lakes) or by small bacterivores and larger herbivores (in the macrophyte-dominated lakes). Ciliate collapse at the beginning of summer coincided with the increase in MZP numbers. It is known that MZP prey intensively on ciliates (e.g. Heinbokel \& Beers, 1979) and can so affect their numbers. According to Laybourn-Parry (1992), also the competition for food resources may be one of the main aspects controlling the temporal patterns of protozoan occurrence and abundance. It is unlikely that there exists sharp food competition between MZP and small bacterivorous ciliates. The macrophyte-dominated lakes showed generally lower MZP abundances than 
the plankton-dominated ones - and in the former the larger herbivorous ciliates were not suppressed during summer. So the small bacterivorous ciliates were more important in plankton-dominated lakes - causing higher summer peaks in abundance. This implies that the microbial loop must be considerably stronger in the plankton-dominated lakes. Our experiments showed a quite clear pattern: in the plankton-dominated lakes (L. Kaiavere and L. Võrtsjärv's central part) the ciliates' grazing rate on bacteria is higher than in the macrophyte-dominated ones (L. Prossa and L. Võrtsjärv's southern part). However, in grazing on small algae the highest rates were found in the macrophyte-dominated lakes (Fig. 4). This suggests that the microbial loop is weaker in macrophyte-dominated lakes and grows stronger when the lake enters the turbid state of plankton-dominated lakes. Yet we can see that the role of ciliates is important in both lake types as consumers of bacteria and small algae.

It is worth mentioning that in L. Kaiavere the maximum grazing rate of MZP coincided with the analogous minimum value in ciliates. Also in L. Võrtsjärv there was a negative trend between these two parameters. We can observe the same trend in grazing rates upon small algae. In L. Võrtsjärv both peaks in MZP grazing rates coincided with the sharp drop in the grazing rates of ciliates and in L. Kaiavere the grazing rate of ciliates dropped as the MZP grazing turned more important (Figs 5 and 6).

We found a negative trend between MZP filtering rate and Chl a concentrations in L. Prossa, which implies that zooplankters have an important role in achieving the clear-water phase. However, as the number of measurements was small, all the correlations were statistically not significant.

As the dynamics of nutrients was rather similar in both macrophyte- and plankton-dominated lakes, the different nutrient availability could hardly be the reason for the observed Phy decline in the macrophyte-dominated lakes in summer. In our study lakes the zooplankton had also a rather similar dynamics. The only observed difference was the summer dominance of herbivorous ciliates in the macrophyte lakes and hence also higher grazing rates on Phy. More intensive ciliate grazing can act as one factor causing a decrease in Phy numbers. Besides that the possible allelopathic influence of macrophytes on Phy, which was not checked, remains almost the only explanation for the observed clear-water phase.

\section{ACKNOWLEDGEMENTS}

Funding for this research was provided by the target-financed project $0362480 \mathrm{~s} 03$ of the Estonian Ministry of Education and Research, by grant No. 4080 of the Estonian Science Foundation, and by the European Commission's Environment and Sustainable Development Program under contract EVK1-CT1999-39 (ECOFRAME). We appreciate Dr. Lauri Arvola's (University of Helsinki) good will to provide microscope equipment. 


\section{REFERENCES}

Arvola, L. 1981. Spectrophotometric determination of chlorophyll $a$ and phaeopigments in ethanol extractions. Ann. Bot. Fenn., 18, 221-227.

Balushkina, E. V. \& Winberg, G. G. 1979. Relation between body mass and length in planktonic animals. In Common Research Methods of Water Ecosystems (Winberg, G. G., ed.), pp. 169172. Nauka, Leningrad (in Russian).

Bilaletdin, Ä., Järvet, A. \& Vehviläinen, B. 1998. Watershed modelling. In Present State and Future Fate of Lake Võrtsjärv. Results from Finnish-Estonian Joint Project in 1993-1997 (Huttula, T. \& Nõges, T., eds), pp. 31-59. Tampere.

Canfield, D. E., Shireman, J. V., Collie, D. E., Haller, W. T., Watkins, C. E. \& Maceina, M. J. 1984. Prediction of chlorophyll $a$ concentrations in Florida lakes: importance of aquatic macrophytes. Can. J. Fish. Aquat. Sci., 41, 497-501.

Cole, J. J., Findlay, S. \& Pace, M. L. 1988. Bacterial production in fresh and saltwater ecosystems: a cross-system overview. Mar. Ecol. Prog. Ser., 43, 1-10.

Crumpton, W. G., Isenhart, T. M. \& Mitchell, P. D. 1992. Nitrate and organic N analyses with second derivative spectroscopy. Limnol. Oceanogr., 37(4), 907-913.

Ducklow, H. W. \& Carlson, C. A. 1992. Oceanic bacterial production. Adv. Microb. Ecol., 12, 113 181.

Edler, L. (ed.) 1979. Recommendations on Methods for Marine Biological Studies in the Baltic Sea. Phytoplankton and Chlorophyll. The Baltic Marine Biologists Publ. No. 5.

Finlay, B. J. 1982. Procedures for the isolation, cultivation and identification of protozoa. In Experimental Microbial Ecology (Burns, R. G. \& Slater, J. H., eds), pp. 44-65. Blackwell Scientific Publications, Oxford.

Flett, R. J., Hamilton, R. D. \& Campbell, N. E. R. 1976. Aquatic acetylene-reduction techniques: solutions to several problems. Can. J. Microbiol., 22(1), 43-51.

Foissner, W. \& Berger, H. 1996. A user-friendly guide to the ciliates (Protozoa, Ciliophora) commonly used by hydrobiologists as bioindicators in rivers, lakes, and waste waters, with notes on their ecology. Freshwater Biol., 35, 375-482.

Grasshoff, K., Kremling, K. \& Ehrhardt, M. (eds) 1999. Methods of Seawater Analysis. Third edition. Wiley-VCH, Weinheim.

Hambright, K. D., Zohary, T., Easton, J., Azoulay, B. \& Fishbein, T. 2001. Effects of zooplankton grazing and nutrients on the bloom-forming, $\mathrm{N}_{2}$-fixing cyanobacterium Aphanizomenon in Lake Kinneret. J. Plankton Res., 23(2), 165-174.

Heinbokel, J. F. \& Beers, J. R. 1979. Studies on the functional role of tintinnids in the Southern California Bight. 3. Grazing impact of natural assemblages. Mar. Biol., 52, 23-32.

HELCOM. 1988. Guidelines for the Baltic Sea Monitoring Programme for the third stage. Baltic Sea Environm. Proc., Helsinki Commiss., Helsinki, 27.

Hilmer, T. \& Bate, G. C. 1989. Filter types, filtration and post-filtration treatment in phytoplankton production studies. J. Plankton Res., 11, 49-63.

Howarth, R. W., Cole, J. J., Marino, R. \& Lane, J. 1988. Nitrogen fixation in freshwater, estuarine and marine ecosystems. 1. Rates and importance. Limnol. Oceanogr., 33(4), 669-687.

Hutchinson, G. E. 1957. A Treatise on Limnology. Vol. I. Geography, Physics and Chemistry. John Wiley \& Sons, New York.

Hutchinson, G. E. 1967. A Treatise on Limnology. Vol. II. Introduction to Lake Biology and the Limnoplankton. John Wiley and Sons, New York.

Jeffrey, S. W., Mantoura, R. C. F. \& Wright, S. W. (eds) 1997. Phytoplankton Pigments in Oceanography: Guidelines to Modern Methods. UNESCO Publishing.

Jensen, J. P., Jeppesen, E., Olrik, K. \& Kristensen, P. 1994. Impact of nutrients and physical factors on shift from cyanobacterial to chlorophyte dominance in shallow Danish lakes. Can. J. Fish. Aquat. Sci., 51, 1692-1699. 
Jeppesen, E., Søndergaard, M., Søndergaard, M. \& Christoffersen, K. (eds) 1998. The Structuring Role of Submerged Macrophytes in Lakes. Ecological Studies, 131. Springer, New York.

Kisand, V. \& Nõges, T. 1998. Seasonal dynamics of bacterio- and phytoplankton in large and shallow eutropic Lake Võrtsjärv, Estonia. Int. Rev. Hydrobiol., 83, 205-216.

Kisand, V. \& Zingel, P. 2000. Dominance of ciliate grazing on bacteria during spring in a shallow eutrophic lake. Aquat. Microb. Ecol., 22, 135-142.

Kufel, L., Prejs, A. \& Rybak, J. I. (eds) 1997. Shallow Lakes '95. Hydrobiologia, 342/343.

Lampert, W. \& Taylor, B. E. 1985. Zooplankton grazing in a eutrophic lake: implications of diel vertical migration. Ecology, 66, 68-82.

Lauridsen, T. L. \& Buenk, I. 1996. Diel changes in the horizontal distribution of zooplankton in the littoral zone of two shallow eutrophic lakes. Arch. Hydrobiol., 137(2), 161-176.

Laybourn-Parry, J. 1992. Protozoan Plankton Ecology. Chapmann \& Hall, London.

Levine, S. N. \& Schindler, D. W. 1992. Modification of the N:P ratio in lakes by in situ processes. Limnol. Oceanogr., 37(5), 917-935.

Levine, S. N. \& Schindler, D. W. 1999. Influence of nitrogen to phosphorus supply ratios and physicochemical conditions on cyanobacteria and phytoplankton species composition in the Experimental Lakes Area, Canada. Can. J. Fish. Aquat. Sci., 56, 451-466.

Lignell, R. 1992. Problems in filtration fractionation of ${ }^{14} \mathrm{C}$ primary productivity samples. Limnol. Oceanogr., 37, 172-178.

Moss, B., Beklioglu, M., Carvalho, L., Klinic, S., McGowan, S. \& Stephen, D. 1997. Vertically challenged limnology; contrasts between deep and shallow lakes. Hydrobiologia, 342/343, 257-267.

Niemi, M., Kuparinen, J., Uusi-Rauva, A. \& Korhonen, K. 1983. Preparation of algal samples for liquid scintillation counting. Hydrobiologia, 106, 149-159.

Nõges, P., Järvet, A., Tuvikene, L. \& Nõges, T. 1998. The budgets of nitrogen and phosphorus in shallow eutrophic Lake Võrtsjärv. Hydrobiologia, 363, 219-227.

Patterson, D. J. \& Hedley, S. 1992. Free-living Freshwater Protozoa. A Color Guide. Wolfe Publishing, England.

Porter, K. G. \& Feig, S. Y. 1980. The use of DAPI for identifying and counting aquatic microflora. Limnol. Oceanogr., 25, 943-948.

Présing, M., Herodek, S., Vörös, L. \& Kobor, I. 1996. Nitrogen fixation, ammonium and nitrate uptake during a bloom of Cylindrospermopsis raciborskii in Lake Balaton. Arch. Hydrobiol., 136(4), 553-562.

Ruttner-Kolisko, A. 1977. Suggestion for biomass calculation of planktonic rotifers. Arch. Hydrobiol., 8, 71-76.

Scheffer, M. 1998. Ecology of Shallow Lakes. Chapman \& Hall, London, Madras.

Smith, V. H. \& Bennett, S. J. 1999. Nitrogen:phosphorus supply ratios and phytoplankton community structure in lakes. Arch. Hydrobiol., 146, 37-53.

Søndergaard, M. \& Moss, B. 1998. Impact of submerged macrophytes on phytoplankton in shallow freshwater lakes. In The Structuring Role of Submerged Macrophytes in Lakes (Jeppesen, E., Søndergaard, M., Søndergaard, M. \& Christoffersen, K., eds), pp. 115-132. Springer-Verlag, New York.

Steeman-Nielsen, E. 1952. The use of radioactive carbon $\left({ }^{14} \mathrm{C}\right)$ for measuring primary production in the sea. J. Cons. Perm. Int. Explor. Mer., 18, 117-140.

Stewart, W. D. P., Fitzgerald, G. P. \& Burris, R. M. 1967. In situ studies on $\mathrm{N}_{2}$ fixation using the acetylene reduction technique. Proc. Natn. Acad. Sci. U.S.A., 58, 2071-2078.

Timms, R. M. \& Moss, B. 1984. Prevention of growth of potentially dense phytoplankton populations by zooplankton grazing in the presence of zooplanktivorous fish, in a shallow wetland ecosystem. Limnol. Oceanogr., 29, 472-486.

Tõnno, I. \& Nõges, T. 2003. Nitrogen fixation in a large shallow lake: rates and initiation conditions. Hydrobiologia, 490, 23-30. 
Utermöhl, H. 1958. Zur Vervollkommnung der quantitativen Phytoplankton Methodik. Mitt. Int. Ver. Theor. Angew. Limnol., 9, 1-38.

Wicks, R. J. \& Robarts, R. D. 1987. The extraction and purification of DNA labelled with [methyl3H]thymidine in aquatic bacterial production studies. J. Plankt. Res., 9, 1159-1166.

\title{
Ökoloogiliste protsesside võrdlus madalates makrofüüdi- ja planktonijärvedes
}

\author{
Priit Zingel, Peeter Nõges, Lea Tuvikene, Tõnu Feldmann, Ain Järvalt, \\ Ilmar Tõnno, Helen Agasild, Helen Tammert, Helen Luup, Jaana Salujõe \\ ja Tiina Nõges
}

On kirjeldatud ökoloogilisi protsesse kolmes eri tasakaaluseisundis olevas madalas järves: planktoni-, makrofüüdi- ja veel ühes järves, kus esinevad mõlemad seisundid. Uuringud on keskendunud nii abiootilistele faktoritele kui ka toitumisahela erinevatele lülidele. Makrofüüdi- ja planktonijärved erinevad selgelt vee läbipaistvuselt, mis on märgatavalt suurem makrofüüdijärvedes ja mille tingib fütoplanktoni suvine madalseis. Mõlemad järvetüübid on sarnased toitainete ja zooplanktoni dünaamikalt, mis tähendab, et fütoplanktoni madalseisu makrofüüdijärvedes tingib mingi alternatiivne kontrollmehhanism. Ripsloomadest domineerivad makrofüüdijärvedes herbivoorsed vormid. Ripsloomade intensiivsem toitumissurve fütoplanktonile võib olla üheks põhjuseks, miks fütoplanktoni hulk väheneb. Peale selle võib fütoplanktoni hulka vähendada ka suurtaimede allelopaatiline mõju, kuigi seda antud töös pole uuritud. Planktonijärvedes sõltub bakterite arvukus fütoplanktoni produktsioonist. Makrofüüdijärvedes pole sellist seost leitud. Planktonijärvedes on ripsloomade bakteritest toitumise kiirus suurem kui makrofüüdijärvedes. Juhul kui aga toitutakse vetikatest, on pilt vastupidine - suuremad toitumiskiirused on leitud makrofüüdijärvedest. Sellest võib järeldada, et makrofüüdijärvedes on mikroobne ling nõrgem ja tugevneb, kui järv muutub häguseveeliseks planktonijärveks. 